\title{
Research on Entrepreneurship Education of College Students Based on Electronic Commerce
}

\author{
Lin Qian \\ Commercial college \\ Yuxi Normal University \\ Yuxi, P. R. China \\ linda.edu@163.com
}

\begin{abstract}
Entrepreneurship education is a new talent training mode in college education. China's higher education institutions are constantly exploring more practical ways of entrepreneurship education to enhance college students' entrepreneurial awareness and to improve their entrepreneurial ability. The popularity of the Internet has greatly changed people's lifestyles, and it is realistic for college students to use ecommerce. This article takes 'e-commerce' course as an example, and carries out curriculum design based on entrepreneurship education. In the process of teaching, the learning enthusiasm of students is greatly mobilized through the introduction of entrepreneurship. The practical teaching design includes four stages, learn, simulation, practice and actual combat. It enables students to gain entrepreneurial knowledge, master entrepreneurial skills and improve entrepreneurial quality in the entrepreneurial experience.
\end{abstract}

Keywords-Entrepreneurship education; Entrepreneurship ability; E-commerce

\section{INTRODUCTION}

With the advent of the era of economic globalization and ecommerce, entrepreneurial enterprises have played an increasingly important role in creating jobs and promoting social and economic growth. Entrepreneurial activities have become the driving force for economic growth. According to statistics, Chinese college graduates have reached 8.2 million in 2018, which is called 'the most difficult employment season in history'. The call for strengthening college students' entrepreneurship education is growing with the severe employment situation of college students.

'Entrepreneurship Education' is translated from the English phrase 'Entrepreneurship Education', which mainly refers to the cultivation of youth's professionalism, enterprising spirit, and adventurous spirit. As a new talent training mode of higher education, entrepreneurship education is a new educational concept put forward by UNESCO in the late 1980s. Entrepreneurship education aims to improve the risk-taking, entrepreneurial ability, innovation consciousness, management and crisis management of university graduates. Strengthen the cultivation of college students' entrepreneurial psychological quality, and improve the overall quality of university graduates by systematic education to meet the current economy. The society's requirements for college students' entrepreneurial spirit and innovative ability.

\section{CURRENT STATUS OF ENTREPRENEURSHIP EDUCATION}

At present, entrepreneurship education has received widespread attention in universities in developed countries. In the United States, more than 1,000 colleges and universities have opened entrepreneurship courses and formed a relatively complete entrepreneurial education system. For example, there is a special institution at Harvard University to guide and support entrepreneurial education for students. Through the entrepreneurial education, the entrepreneurial potential of these students is well developed, and the entrepreneurial skills of students are improved. Therefore, $40 \%$ of the MBA graduates regard the entrepreneurship as a personal lifelong pursuit. Compared with foreign countries, domestic entrepreneurship education started later. In 1998, Tsinghua University established the China Entrepreneurship Research Center and began the research and promotion of entrepreneurship education in China. In 2010, the Ministry of Education issued the Opinions on Promoting Innovation and Entrepreneurship Education and College Students' Self-employment Work, and established the Entrepreneurship Education Steering Committee. In 2012, the Ministry of Education issued the Notice on Doing a Good Job in the Implementation of the Undergraduate Teaching Project for National College Students' Innovation and Entrepreneurship Training Program, emphasizing the need to incorporate the daily management of the University's Innovation and Entrepreneurship Training Program into the undergraduate teaching management system. Colleges and universities in China have gradually carried out entrepreneurship education and research, and have achieved initial results in entrepreneurship courses and entrepreneurial teaching methods. 


\section{A. Economic environment analysis}

With the popularity of the Internet, the advantages of online shopping have become more prominent and increasingly become an important form of shopping. According to the China Internet Network Center (CNNIC) report, as of June 2018, the number of Chinese netizens reached 802 million, with a penetration rate of $57.7 \%$. The number of online shopping users has reached 569 million, with a semi-annual growth rate of $6.7 \%$. It can be seen that China's online shopping application is in a relatively fast development channel, and the use of ecommerce entrepreneurship has broad market prospects and realistic feasibility.

\section{B. Preferential policy analysis}

In order to support college students in carrying out entrepreneurial activities, the state and government departments at different levels have introduced many preferential policies in financing, opening, taxation, entrepreneurship training, and entrepreneurship guidance. For small micro-enterprises established by college graduates, the monthly sales of not more than 20,000 yuan will be temporarily exempted from VAT and business tax; those engaged in lowprofit projects can enjoy financial subsidies of no more than 100,000 yuan. College graduates who run 'online stores' on the Internet platform can enjoy small-sum secured loans and interest subsidy policies.

\section{School environment analysis}

In order to support college students' entrepreneurship, colleges and universities not only offer entrepreneurship education courses, but also help college students to lay the foundation for entrepreneurial knowledge. Conditional universities are actively providing students with a stage for entrepreneurial practice. For example, the 'College Student Pioneer Park' and the 'School-Enterprise Cooperation Base' are created to use the online platform for online transactions. Entrepreneurship education and entrepreneurship training carried out during the university have improved the entrepreneurial ability of college students, which makes it more feasible for college students to use e-commerce for entrepreneurship. competition, and the entrepreneurship only stayed on the plan, and there is no real entrepreneurial practice.

\section{Feasibility Analysis of College Students' Use of E-COMMERCE}

The popularity of the Internet has greatly changed people's lifestyles. The application of e-commerce has penetrated into various fields of social economy, which provides the necessary premise for college students to use e-commerce. The number of Chinese netizens has reached 802 million, of which the most active and most influential young people account for about $55 \%$. It can be seen that the use of e-commerce entrepreneurship has broad market prospects, and it is feasible for college students to use e-commerce.

\section{Self-advantage analysis}

As the younger group with higher education, the most remarkable feature of college students is their rich theoretical knowledge. At the same time, college students are familiar with a variety of computer software, have a wide range of applications for computers, and provide technical support for college students e-commerce entrepreneurship. According to statistics, the proportion of netizens in the 20-29 age group is $27.9 \%$. Netizens in this age group are also the backbone of online shopping. College students can better grasp the preferences of netizens of this age group, and better understand the real needs of customers, so as to achieve more targeted entrepreneurship. Of course, college students also have disadvantages in starting a business, such as lack of social experience, lack of management and operational experience. However, using e-commerce to make up for these 
shortcomings makes it more practical and feasible for college students to use e-commerce.

\section{TEACHING DESIGN OF E-COMMERCE COURSE BASED ON ENTREPRENEURSHIP EDUCATION}

The curriculum is the core link of entrepreneurship education. Taking the curriculum as the entry point for entrepreneurship education is a feasible way to carry out entrepreneurship education in colleges and universities. The following is an example of the e-commerce course, which is based on entrepreneurship education.

\section{A. Course teaching method}

E-commerce is a new and practical course. Teachers should use a variety of teaching methods in the teaching process to continuously stimulate students' interest in learning and achieve good teaching results.

\section{1) Case teaching method}

In the classroom teaching, the use of vivid cases allows students to discuss and analyze, and to improve students' ability to analyze and solve problems while deepening their understanding of theoretical knowledge. In particular, some successful entrepreneurial cases, such as Ma Yun, Kai-Fu Lee, Bill Gates' entrepreneurial history, stimulate students' entrepreneurial enthusiasm. For example, in the grouppurchasing mode of learning, the first domestic group-buying website 'Mei Tuanwang' was cited as a case study and combined with video, from the development process of Meituan.com to the current enterprise scale and website characteristics. Through the case study, students have a specific understanding of the development status of China's grouppurchasing websites, the types of group-purchasing websites, application models, and profit models. At the same time, the enthusiasm for using e-commerce entrepreneurship is constantly rising.

\section{2) Group teaching method}

Students are divided into groups, each of which assigns a task, and the team members work together to complete the learning task. In the process of group teaching, students complement each other's strengths, cultivate the ability of teamwork, and lay a solid foundation for entrepreneurship. For example, in the online learning task, students are required to experience online shopping and online shopping as a group and as a store, and to cultivate students' comprehensive ability in online sales and online store operations. Through cooperative learning, each group has opened an online store and displayed the store at the end of the semester. The teacher commented on the results of the exhibition, which not only consolidated and practiced the subject knowledge, but also improved the comprehensive ability of students to use e-commerce.

\section{3) Role-playing method}

According to the content of the course, aiming at the completion of a certain task, let the students experience the specific practice of certain behaviors in the process of roleplaying, and apply the theoretical knowledge to the actual work The role-playing method can fully mobilize the enthusiasm and initiative of students, understand the mentality and behavior of different roles in practice, and prepare for entrepreneurship.

\section{4) Experimental simulation method}

Through the simulation of laboratory software, students can experience the whole process of entrepreneurship. For example, in the learning process of $\mathrm{B} 2 \mathrm{C}$ transaction mode, the ecommerce environment such as virtual banking, logistics center, EDI data exchange center, etc. is provided through experimental simulation method, which provides students with a process platform in the simulated real environment for students to practice and use. In the simulated entrepreneurial practice, students are helped to analyze the problems that may arise during the entrepreneurial process, so that students can have a deeper understanding of entrepreneurship.

\section{B. Course content design}

In the process of e-commerce teaching, we will create a teaching mode that integrates 'teaching', 'learning' and 'doing' With the goal of cultivating students' skills, we will take simulation experiments with e-commerce laboratory software and online store operation management as the main line. Using case analysis team cooperation and other teaching methods to implement teaching, using multimedia, network resources and other teaching methods to carry out teaching. The e-learning course practice teaching process is divided into the following four main stages.

\section{1) Learning stage}

The professional theoretical knowledge, business management knowledge and comprehensive knowledge of ecommerce are taught to students. At the same time, students are taught effective learning methods, establish the concept of lifelong learning, cultivate students' entrepreneurial awareness, and stimulate students' strong entrepreneurial confidence and determination.

\section{2) Simulation stage}

Using the Boss e-commerce teaching experiment system, students can gain an in-depth understanding of e-commerce business processes through simulation experiments. The main roles include consumers, manufacturing companies, shopping malls, CA centers, banks, and logistics companies. By playing different roles, students go to the entire business process from the production company out of the warehouse, logistics process, the mall, and then through the logistics process to reach the consumer. Learning in the simulation phase can enable students to have a comprehensive and holistic understanding of the ecommerce system and its processes, as well as a preliminary understanding of the skills of each business position. 


\section{CONCLUSION}

\section{3) Practical stage}

Students are grouped independently to conduct entrepreneurial practice activities in small groups. The team members set up their entrepreneurial direction according to their own interests and resources, and write a preliminary business plan under the guidance of the teacher. Conduct a questionnaire survey, collect feedback and suggestions, and modify the business plan. Students are encouraged to actively participate in various entrepreneurial competitions and form a perfect business plan in the competition.

\section{4) Actual stage}

Taobao is China's largest e-commerce trading platform. It provides a personal-to-individual trading model with the features of free shop opening, simple operation and low barriers. It also has a comprehensive security system, including Alipay and logistics distribution guarantee services and so on. Therefore, more and more college students are investing in online entrepreneurship, and Taobao has become the firstchoice platform for college e-commerce entrepreneurs to open online stores. Under the guidance and help of the teachers, students are encouraged to open online stores, and experience the e-commerce operation process in actual combat. At the same time, they can also cultivate students' entrepreneurial awareness and improve their entrepreneurial ability.

\section{Course evaluation design}

The e-commerce course based on entrepreneurship education is an innovative education model. Therefore, it is necessary to establish a matching curriculum evaluation system. The course evaluation not only pays attention to academic achievements, but also attaches importance to entrepreneurial skills and innovative spirit, making the evaluation and assessment work routine and paying attention to the development of students in daily teaching activities. Diversified methods are adopted in the assessment content, such as reducing the proportion of written test scores, and increasing the evaluation methods combining experimental reports and practical results.
With the continuous development of college students' entrepreneurship, higher education institutions are constantly exploring more practical ways of entrepreneurship education. The e-commerce course based on entrepreneurship education integrates 'teaching', 'learning' and 'doing'. Through the use of various teaching methods, the enthusiasm of students is greatly mobilized. The four-stage practical teaching design enables students to gain entrepreneurial knowledge, master entrepreneurial skills, and improve entrepreneurial quality in a real entrepreneurial experience.

\section{REFERENCES}

[1] Liu Hongda. Self-employment education and practice guidance for college students[M]. Science Press. April 2011. (In Chinese)

[2] Dong Qingchun. Foundation of College Students' Entrepreneurship[M]. Economic Management Press. July 2012. (In Chinese)

[3] Yang Xiaohui. Report on the Development of Employment and Entrepreneurship of Chinese University Students[M]. People's Publishing House. January 2018. (In Chinese)

[4] Michaels Research Institute. 2018 China University Student Employment Report [M]. Social Science Literature Publishing House. June 2018. (In Chinese)

[5] China Internet Network Information Center. Statistical Report on the Development of China's Internet Network [R]. August 2018. (In Chinese) 